\title{
A Complete Product Design Realization Experience Through Integrating a Computer Integrated Manufacturing Course with an Automotive Capstone
}

\author{
Jacqueline El-Sayed, Lucy King, Mohamed El-Sayed \\ Kettering University, Flint, Michigan 48504
}

\begin{abstract}
Engineering capstone classes are the culmination of a student's academic experiences. The objective is for the student to use much of their engineering knowledge base to design a system or component for a set of design requirements. This usually entails a detailed team project with the design criteria, product drawings, analysis, parts list, product costs, discussion and conclusions. If the design is fabricated at all, it is done so in a rudimentary fashion. The team usually consists of other students in the same capstone class, which therefore means all team members are of the same major, so these students tend to have very similar engineering perspectives.

At Kettering University, a process is being developed to integrate engineering students of both mechanical and manufacturing backgrounds into design teams. Most recently this process has been applied to the automotive-specialty capstone within the Mechanical Engineering department and the computer integrated manufacturing class within the IME Department. The automotive-specialty capstone student teams are charged with designing a vehicle. Within the teams, leaders are chosen to be responsible for various aspects of the design. The CIM students are integrated with these design teams, with one leader chosen to be responsible for the manufacturing of the design, an aspect of the design project that previously was not developed in detail. Manufacturing students provide input into the feasibility of manufacturing the part, the manufacturing processes, material selection, tolerancing and quality issues. The students meet regularly inside and outside the classroom to perfect their design, analysis, documentation, and actually fabricate a component of each vehicle. Through interaction and practical experience, the students learn lessons in design for manufacturability and working in multidisciplinary teams that they would not have without the course integration. A class overview, schedule, and methodology is included, as well as the assessment results.
\end{abstract}

\section{Introduction}

Traditionally, engineering design and manufacturing have been seen as totally separate areas of expertise. Engineers specializing in design and those experienced in manufacturing had an ongoing rivalry. This type of rivalry also existed between engineers from different disciplines and industrial positions. Engineers involved in design and those involved in manufacturing struggle to complete a product. Communication between the groups involves finger-pointing, and taking credit.

"Proceedings of the 2004 American Society for Engineering Education Annual Conference \& Exposition Copyright (C) 2004, American Society for Engineering Education” 
This state of affairs also exists in academia. Courses are usually compartmentalized, and little interaction occurred between engineering professors in the same area, and even less interaction occurs outside of discipline boundaries. Professors struggle to control their territories and this uneasiness is passed on to students. In this work, a group of colleagues at Kettering University, have introduced a new teaching process ${ }^{1,2,3,4}$. This process includes integrating classes both vertically and horizontally. Vertical integration refers to courses connected with in the same department, while horizontal integration refers to courses connected between different departments. Integration is being developed between manufacturing, industrial and mechanical engineering courses. The main goal is to develop a streamlined process where students move from one course to another, carrying with them the knowledge and skills from upstream courses and the ability to visualize what is expected in the downstream classes. This holistic learning approach forms the foundation of a solid multi-disciplinary education. Therefore, it is extremely important to build continuity among sequences of courses. Students can then move along the thread that intertwines seamlessly among the courses in the curriculum.

This paper presents an integration attempt of an engineering capstone course in Mechanical engineering (ME) and an upper level manufacturing course in Industrial and Manufacturing engineering. Engineering (IME) capstone classes are the culmination of a student's academic experiences. The intention for the ME capstone class is for the student to use much of their engineering knowledge base to design a system or component for a set of design requirements. This usually entails a detailed team project with the objectives, design drawings, analysis, discussion, parts list, costs, and conclusions. If the design is fabricated at all, it is done so in a rudimentary fashion. The team usually consists of other students in the same capstone class, which therefore means all team members are of the same major, so these students tend to have very similar engineering perspectives.

The two courses chosen for the integration process was the automotive-specialty capstone within the ME department and the computer integrated manufacturing class within the IME Department. The automotive-specialty capstone student teams are charged with designing a vehicle of their choice. Within the teams, leaders are chosen to be responsible for various aspects of the design. The CIM students are integrated into these design teams, with one leader chosen to be responsible for the manufacturing of the design, an aspect of the design project that previously was not developed in detail. Manufacturing students provide input into the feasibility of manufacturing the part, the manufacturing processes, material selection, tolerancing and quality issues. The students should meet regularly inside and outside the classroom to perfect their design, analysis, documentation, and actually fabricate a component of each vehicle. This allows the students to participate in a complete product design realization experience. This type of design actualization gives students comprehensive perception of engineering reality in real life settings. ${ }^{5,6}$ Through interaction and practical application in this experience, the students learn lessons in design for manufacturability and working in multidisciplinary teams that they would not have without the course integration. The lessons learned in this type of collaborative environment should foster better understanding between engineers in different academic disciplines and engineers involved in different positions in industry. This understanding of the product development cycle in combination with multidisciplinary communication experience should offer a significant contribution to the field of engineering as a whole.

\footnotetext{
"Proceedings of the 2004 American Society for Engineering Education Annual Conference \& Exposition Copyright $\mathbb{C}$ 2004, American Society for Engineering Education"
} 


\section{Background}

In order to develop a process to integrate two courses, those instructors involved must have a thorough understanding of the topics covered and the assessment methods of each course. Following is an overview of the Automotive Capstone course (MECH-448) and the Computer Integrated Engineering course (IME-409)

\section{Automotive Capstone (MECH-448)}

The objective of the automotive capstone is to follow the design process of an automobile from the beginning to the end. The experience in this class should culminate the educational experiences from all the preceding courses. This experience should foster creativity. The students should develop, simulate, and evaluate their designs. The majority of the assessment of this class is based on a capstone project, which consists of a detailed design report including computer drawings, assemblies, analysis, and simulations. Lectures are given to teach students about the topics they will need for this work and are more frequent in the beginning of the class. Individualized meetings between the instructor and the teams occur from the beginning and are more frequent as the class progresses.

After creative design using brainstorming techniques, the students should identify the product attributes. They then transform these attributes to engineering requirements. They should account for manufacturability. Using teamwork, they must simulate the process and analyze the design for engineering requirements. The students give a written and oral proposal, progress report and final report, so communication skills are evaluated.

Examples of past machine design capstone projects include: Design of a fully automated lawn mower system; a fully automated house system that prepares food and drinks and serves them, etc.; a handicapped mountain climbing chair; a fully automated unmanned service station; a convertible, reconfigurable stadium; and an automated home entertainment center. The automotive capstone is similar to the machine design capstone but focuses on the automotive industry. Examples of past automotive capstone projects include: a three wheeled all terrain vehicle; an armored vehicle; and a military vehicle with an electric power train for stealth.

The students act like a company. They choose a chief engineer and under him/her a design engineer, chassis engineer, body engineer, etc. After choosing what kind of vehicle they wish to design based on either their "dream car" or what they think the market needs, the team develops the architectural concept and the performance desired. Weeks 1-3 the team works to complete the bill of product, and the bill of design. Weeks 4-7 they must complete the bill of material and a subset of this the bill of architecture and the bill of performance. To do this, the team must do the simulation that consists of hand calculations, FEM, and computer programs for such things as fuel economy and 0-60 speed calculations. Weeks 7-10 involve the design synthesis to finalize the project. Here alternatives must be considered, and their trade off in performance. They also must develop the bill of process.

"Proceedings of the 2004 American Society for Engineering Education Annual Conference \& Exposition Copyright $\mathbb{C}$ 2004, American Society for Engineering Education" 
Computer Integrated Manufacturing (IME-409)

The CIM course's objective is to teach the students all phases of computer integrated manufacturing, so that they can design a complete plant operation or any subsystem thereof. The topics include the overview, safety, automation including operation and language, manufacturing parameters and analysis tools. This class also acts as a company that has a CEO, directors, managers and engineers. This company must manufacture the given components. All parts of the manufacturing design must be taken into consideration. Manufacturing students' work on material selection, procurement, process design and simulation, manufacturing planning, automation requirements and implementation plan.

During weeks 1-3 students work on a proposal for design that includes initial sequence of operations, budget, and material selection. Weeks 4-7 an interim progress report that includes detailed drawings, analysis, material procurement, manufacturing operations, procure devices, build prototype is completed. The final build and work cell construction is finished during weeks 8-11. Example projects are small parts such as desktop utility sets, clock and cardholders, CD racks, and jewelry.

\section{Proposed Process for Integration of the classes}

From the interviews of both instructors, a common laboratory schedule was developed The schedule and topics are given in Table 1.

Table 1 - Lab Schedule Developed for Integrated Classes

\begin{tabular}{|c|c|}
\hline Week & Auto Capstone and CIM Common Lab- Mondays 1:20-3:30 PM \\
\hline 1 & $\begin{array}{l}\text { ME: Lecture on creativity, team dynamics, brainstorming techniques; IC: } \\
\text { team building; } \\
\text { IE: Introduction to CIM } \\
\text { Assignment: Project brainstorming session }\end{array}$ \\
\hline 2 & $\begin{array}{l}\text { ME: Lecture on the design process, product attributes, design criteria, and } \\
\text { proposal writing; } \\
\text { In-Class: Selection of project out of brainstorming list based on certain } \\
\text { criteria; } \\
\text { Assignment: proposal development }\end{array}$ \\
\hline 3 & $\begin{array}{l}\text { IE: Lecture on automation and safety } \\
\text { ME: Lecture on the bill of process, bill of materials. } \\
\text { Assignment: component selected to be prototyped }\end{array}$ \\
\hline 4 & Students present their proposals in class. \\
\hline 6 & $\begin{array}{l}\text { IE: Lecture on concurrent engineering } \\
\text { ME: Lecture on progress report. }\end{array}$ \\
\hline 8 & $\begin{array}{l}\text { Students present progress reports. } \\
\text { Update on component progress to date. }\end{array}$ \\
\hline 10 & $\begin{array}{l}\text { IE: Lecture on CIM topic. } \\
\text { ME: Lecture on final report. }\end{array}$ \\
\hline $\begin{array}{l}11 \\
\text { Final } \\
\text { Exam }\end{array}$ & $\begin{array}{l}\text { Students give final presentations. } \\
\text { CIM students give demonstration of completed manufacturing process for } \\
\text { component. }\end{array}$ \\
\hline
\end{tabular}

IE- CIM (IME-409) class instructor

ME- Automotive Capstone (MECH-448) class instructor

"Proceedings of the 2004 American Society for Engineering Education Annual Conference \& Exposition Copyright $@$ 2004, American Society for Engineering Education" 
Both groups of students would meet for the first four weeks. Starting with the fifth week they would meet every other week until the final week. The CIM students need to be part of the during team formation, brainstorming, and perform selection. The auto students will be the lead in design/ simulation areas, while the CIM students will be the lead in manufacturing areas. A component of the overall design will be selected by the third week. This component will be manufactured by the CIM students and used in their part of the simulation. The auto students will be completing the design simulation and analysis as their part of the project. All students will be present at the presentations and will participate by presenting their designated tasks. The final presentation of the design will be on the eleventh week. The CIM students will present a demonstration of their manufacturing simulation at their scheduled final exam time.

\section{Case Study- Fall 2003}

The developed process was tested in the Fall 2003 term. In the application of the developed process several deviations occurred. The major obstacle was that the courses were not scheduled at the same times. The second obstacle was that the Automotive Capstone class was much larger than the CIM class by a factor of more than 4 with the CIM class having only six students. To handle these obstacles the schedule was modified so that instead of common lectures, the professors gave identical lectures to each class. Labs were modified for students to meet in labs outside of class time. In order to compensate for the small CIM class size only one capstone team of six students included all six CIM students. This integrated capstone team's project dealt with the design, organization, and fabrication of the SAE formula vehicle. Because the design and fabrication of this vehicle is a vast undertaking, a single component was chosen for product design realization. The wheel hub (Figure 1) was designed, redesigned, and fabricated by the team through automated manufacturing equipment. One prototype was fabricated with the analysis, tooling and programming completed for the fabrication of additional hubs for the vehicle to use in the SAE competition.

The CIM students met and worked with the design students to give input and feedback into the design of the hub. A tolerance analysis resulted in the relaxation of a tolerance of a noncritical dimension. The size of the center bore was crucial and a .0005 tolerance was maintained. The collaboration saved product design \& manufacturing lead-time, by reducing late design changes. This is extremely important, not only because of shortness of the academic term, but it also reflects a real industrial environment. Fixtures to achieve the prescribed tolerance were designed and fabricated for work-holding in the mill and lathe. Process plans and operation sequences were laid out guiding the fabrication process. The wheel hub's aluminum parts were produced. Cost was a main concern. Students obtained some support from their co-op employers in the form of fabricated fixtures that reduced expenditures.

"Proceedings of the 2004 American Society for Engineering Education Annual Conference \& Exposition Copyright (C) 2004, American Society for Engineering Education” 


\section{Figure 1. Wheel Hub}

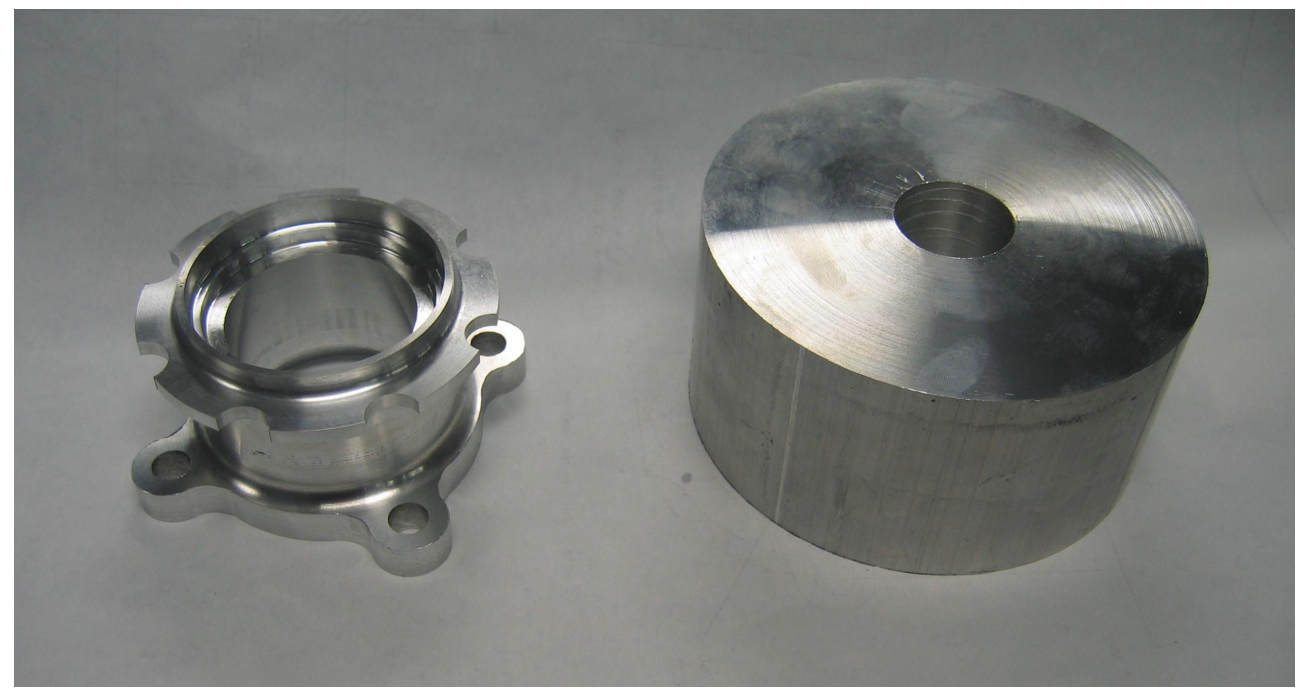

An additional course integration was included. The analysis of the chosen component, the wheel hub, was "out-sourced" to an analysis team from the FEM (MECH-516) class, which acted as an external analysis group. The details of the analysis were communicated through a student liaison from the capstone team. The student analysis group returned their results to the student liaison, who was responsible for communicating all necessary requirements, geometries, and details to the team.

When the final report was completed, the team including the capstone, CIM, and FEM students, gave the final presentations to the three classes, instructors, and invited industrial personnel. Manufacturing student team members demonstrated the computer integrated manufacturing techniques they employed to fabricate the wheel hub prototype.

\section{Assessment}

A survey was developed and distributed to each team participant to assess their perceptions on the value and learning outcomes of the course integration. The survey is shown in Figure 2. The results of the survey included questions about the students' increased understanding of communications blocks and potential problems between team members from different backgrounds during interactions.

From the results of the survey, the integration process provided an effective learning environment for students to advance in inter-disciplinary knowledge from their multidisciplinary "Proceedings of the 2004 American Society for Engineering Education Annual Conference \& Exposition Copyright (C) 2004, American Society for Engineering Education” 
partners. Students were enthusiastic about the collaboration that mirrored their endeavor at Kettering and with their co-op experience. Student indicated that this process will benefit their future engineering careers, that they have to keep an open mind about their designs and process plans, that it was a challenging endeavor trying to meet with other students, to practice true teamwork, and to communicate, discuss and compromise their ideas for the betterment of quality and low cost.

Figure 2. Student Survey for Course Assessment

\begin{tabular}{|c|c|}
\hline $\begin{array}{l}\text { This su } \\
\text { of the }\end{array}$ & $\begin{array}{l}\text { Combined Manufacturing and Design Survey } \\
\text { (IME and MECH, Fall 2003) } \\
\text { is to be used for student assessment of the combined team projects } \\
\text { e design class. Please rate on a scale of } 1-10 \text { (10 being the best): }\end{array}$ \\
\hline 1) & $\begin{array}{l}\text { To what extent did this project help you to understand the } \\
\text { interaction between design and manufacturing and help you to } \\
\text { identify potential problems. }\end{array}$ \\
\hline 2) & $\begin{array}{l}\text { To what extent did this project help you realize the importance of } \\
\text { concurrent engineering (simultaneous design and manufacturing) } \\
\text { to eliminate potential problems. }\end{array}$ \\
\hline 3) & $\begin{array}{l}\text { To what extent did the project help you anticipate problems in } \\
\text { industry. }\end{array}$ \\
\hline 4) & $\begin{array}{l}\text { To what extent did you enjoy participating in the making of the } \\
\text { prototype (product realization.) }\end{array}$ \\
\hline 5) & How well did your team work together? \\
\hline 6) & How well did you team members communicate? \\
\hline 7) & $\begin{array}{l}\text { Did you feel that your partners in the other class were as capable } \\
\text { as you were in their areas of expertise? }\end{array}$ \\
\hline 8) & $\begin{array}{l}\text { To what extent did this project help you to see possible } \\
\text { communication blocks? }\end{array}$ \\
\hline 9) & $\begin{array}{l}\text { To what extent did this project help you to learn about working in } \\
\text { multidisciplinary teams and dealing with any problems? }\end{array}$ \\
\hline Please & ay comments about your experience. \\
\hline
\end{tabular}

"Proceedings of the 2004 American Society for Engineering Education Annual Conference \& Exposition Copyright (C) 2004, American Society for Engineering Education” 
Due to the administrative class scheduling change, the classes did not have the planned time overlap. The lack of substantial in-class time was a serious problem, especially for the manufacturing engineering students. This led to delays in the completion of the design, and therefore left less than sufficient time for the completion of the machine programming and manufacture of the prototype. Administrative support is essential for successful implementation of well-developed integration procedures. However, even with this drawback students felt that the process benefited them as engineers and contributed to their understanding of possible industrial communication blocks. They also felt that the project helped them to learn about working in multidisciplinary teams and dealing with any problems that develop.

\section{Conclusion}

At Kettering University, processes are being developed to integrate engineering students of both mechanical and manufacturing backgrounds into design teams. Most recently a process was developed and applied to the automotive-specialty capstone within the Mechanical Engineering department and the computer integrated manufacturing class within the IME Department. While the first case study had major obstacles that were circumvented, the overall process of capstone integration has merit and should be pursued in the future. Areas of major importance to the outcome of any course integration include: administrative buy-in and assistance; instructor preparation; planned project timing; team communication and financial support. When these areas are addressed the goal of a complete product design integration experience can be achieved. This type of experience greatly contributes to a student's ability to conceptualize the product design cycle and is perceived to contribute to the student's success after graduation. 5,6

Bibliography

1. L.S. King, J.A. El-Sayed, “A Structure for Integration of Manufacturing and Mechanical Design Engineering Courses", 2003 ASEE Annual Conference \& Exposition, Nashville, TN June 22-25, 2003

2. L. King, W. Riffe, B. Tuttle, B. Lemke, J. El-Sayed, D. Melton, L. Rust, "Building a Process for Establishing an Integrated Design and Manufacturing Freshman Course", 2003 ASEE Annual Conference \& Exposition, Nashville, TN June 22-25, 2003

3. W. Riffe, L. Rust, D. Melton, B. Lemke, J. El-Sayed, "Combining Design and Manufacturing Into a First Year Course,” ASEE Conference, Toronto, Canada, June 8-10, 2002

4. J. A. El-Sayed, "Industrial-Academic Integration Takes Learning Out of the Classroom," SEFI Annual Conference 2001,September 12-14, Copenhagen, Denmark

5. Terenzini, P. T., Cabrera, A. F., Colbeck, C. L., Parente, J. M., Bjorklund, S. A., "Collaborative Learning vs. Lecture/Discussion: Students' Reported Learning Gains," Journal of Engineering Education, January 2001, pp. 123-130

"Proceedings of the 2004 American Society for Engineering Education Annual Conference \& Exposition Copyright $@$ 2004, American Society for Engineering Education" 
6. Haller, C. R., Gallager, V. J., Weldon, T. L., Felder, R.M., "Dynamics of Peer Education in Cooperative Learning Workgroups", Journal of Engineering Education, July 2000, pp. 285-293

\section{Biographies}

Jacqueline El-Sayed, Ph.D. is an associate professor of Mechanical Engineering at Kettering University, where she teaches a range of courses including Mechanics 1\&2, Finite Element Analysis, Machine Design, and Mechanics of Polymers. Her research interests are in the areas of manufacturing optimization, and integration of engineering curricula. She is active in the Faculty Senate and advises several student organizations.

L. King, Ph. D. has been a professor in Manufacturing Engineering for 10 years at Kettering University and teaches primarily CIM (including CNC), Robotics and evening distance learning graduate degree program courses. She had 12 years of prior teaching experience in $\mathrm{CAD} / \mathrm{CAE} / \mathrm{CAM}$ areas at Lawrence Technological University. As Chair of the Design Engineering Education Committee (DEC) of ASME she was active in organizing sessions in Total Quality in Design Engineering Education, Engineering curricula in pre-college education, and is the liaison and member of the Board on Pre-College. Currently, she is responsible for collaborative effort to incorporate MfgE courses into ME curriculum.

Mohamed El-Sayed, Ph. D. is a professor of Mechanical Engineering at Kettering University and has been teaching for 25 years. He teaches Machine Design, Automotive Design, Design Optimization, and Multidisciplinary Optimization on both the undergraduate and graduate level. He has over fifty research papers of topics ranging from finite element analysis, numerical optimization, and design applications. He is a consultant for several corporations.

"Proceedings of the 2004 American Society for Engineering Education Annual Conference \& Exposition Copyright (C) 2004, American Society for Engineering Education” 